\title{
DAMPAK PEMBERLAKUAN SISTEM ZONASI TERHADAP MUTU SEKOLAH DAN PESERTA DIDIK
}

\author{
Riski Tri Widyastuti \\ Universitas Kristen Satya Wacana, Fakultas Keilmuan dan Ilmu Pendidikan \\ email: riskitriwidyastuti28@gmail.com
}

\begin{abstract}
Problems that occur in Indonesia about education are the lack of equal distribution of education such as facilities in schools that differ from one school to another, the number of students who are not balanced between one school and another school, as well as many parents who complain that their children cannot attend school close to House. The purpose of writing this scientific paper is to determine the positive and negative impacts of the implementation of the Zoning system for students as well as the quality of education. The process of collecting data using Data Triangulation is by collecting a variety of different sources but using the same method in his research. The results showed that 1). Zoning can equalize education 2). There are still deviations from some elements both from parents and schools 3). Zoning affects the students themselves. The results of the study are useful for understanding the implementation of the Zoning System in Indonesia.
\end{abstract}

Keyword: Zoning system, school quality, students

\begin{abstract}
Abstrak: Permasalahan yang terjadi di Indonesia tentang pendidikan adalah kurangnya pemerataan pendidikan seperti fasilitas di sekolah yang berbeda antara satu sekolah dengan sekolah yang lain, jumlah murid yang tidak seimbang antara satu sekolah dan sekolah lain, serta banyaknya orangtua yang mengeluh bahwa anaknya tidak dapat bersekolah yang dekat dengan rumah. Tujuan dari penulisan karya ilmiah ini adalah untuk mengetahui dampak positif dan dampak negatif dari pemberlakuan sistem Zonasi bagi peserta didik maupun mutu pendidikan. Proses pengumpulan data dengan menggunakan Triangulasi Data yaitu dengan mengumpulkan beragam sumber yang berbeda namun menggunakan metode yang sama dalam penelitiannya. Hasil penelitian menunjukkan bahwa 1). Zonasi dapat memeratakan pendidikan 2). Masih terjadi penyimpangan dari beberapa oknum baik dari orangtua maupun sekolah 3). Zonasi berpengaruh terhadap diri peserta didik. Hasil penelitian tersebut berguna untuk memahami tentang pemberlakuan Sistem Zonasi di Indonesia.
\end{abstract}

Kata Kunci : Sistem Zonasi, mutu sekolah, peserta didik

\section{PENDAHULUAN}

Menurut UU No.20 tahun 2003. Pendidikan adalah usaha sadar dan terencana untuk mewujudkan suasana belajar dan proses pembelajaran agar peserta didik secara aktif mengembangkan potensi dirinya untuk memiliki kekuatan spiritual keagamaan, pengendalian diri, kepribadian, kecerdasan, akhlak mulia, serta keterampilan, yang diperlukan dirinya, masyarakat, dan Negara. (Nasional, 2003). Pembangunan suatu Negara tak lepas dari peran pendidikan, bangsa yang terdidik akan menjadikan bangsa 
yang besar sehingga pembangunan pun dapat berjalan dengan baik. Oleh karena itu peran pendidikan dirasakan sangat penting bagi suatu bangsa, selain itu seperti yang tertuang dalam UUD 1945 bahwa pendidikan merupakan hak segala bangsa, hal ini berarti bahwa setiap masyarakat dari golongan apapun berhak merasakan layanan pendidikan tanpa terkecuali. Belajar merupakan sebagai proses perubahan perilaku sebagai hasil interaksi individu dengan lingkungannya. Perubahan perilaku terhadap hasil belajar bersifat continue, fungsional, positif, aktif, dan terarah. (Pt \& Arnilya, 2019). Dengan belajar, otak kita akan terbiasa untuk menganalisis setiap permasalaham yang ada kemudian mencari solusi pemecahannya

Dalam pendidikan formal tahap awal dalam mengikuti suatu pendidikan adalah penerimaan peserta didik baru. Penerimaan peserta didik diharapkan dapat berjalan dengan obyektif, transparan dan tidak diskriminasi terhadap calon peserta didik baru supaya layanan pendidikan dapat dinikmati oleh setiap golongan masyarakat secara merata. Oleh karena itu upaya pemerintah dalam pemerataan pendidikan adalah dengan di keluarkannya aturan baru dalam penerimaan peserta didik melalui Peraturan menteri pendidikan dan kebudayaan No. 51 Tahun 2018 , prinsip dari peraturan ini adalah dalam penerimaan peserta didik baru adalah nondiskriminatif, objektif, transparan , akuntabel , dan berkeadilan untuk mendorong peningkatan akses layanan pendidikan.(Kebudayaan, 2018).

Berdasarkan Permendikbud No.51 Tahun 2018 , sekolah yang diselenggarakan oleh pemerintah wajib menerima peserta didik dengan radius jarak terdekat dari sekolah dengan jumlah minimal $90 \%$ dari seluruh jumlah calon peserta didik yang diterima. Peraturan tentang zonasi ini baru mulai diterapkan tahun 2017 (Dhani Arba, 2019).

Alih-alih sebagai wujud upaya pemerintah dalam upaya pemerataan layanan pendidikan pada kenyataannya masih ada aduan atau keluhan dari orangtua murid yang mengatakan bahwa usaha yang telah dilakukan oleh anaknya untuk mendapatkan nilai UN yang maksimal hanyalah sia-sia karena tidak dapat masuk ke sekolah yang diinginkan sejak lama.

Selain itu masalah lain yang ditimbulkan dari penerapan sistem zonasi yaitu menjadikan polemik bagi guru, terutama guru-guru yang mengajar di sekolah favorit , mereka terbiasa mengajar siswa dengan kemampuan akademik yang tinggi, dengan adanya zonasi guru menjadi kewalahan dan pada akhirnya akan menggunakan cara , strategi, dan metode mengajar yang ekstra untuk menghadapi perubahan tersebut, dampak zonasi juga berdampak pada mutu sekolah sebagai contoh sekolah yang sebelumnya merupakan sekolah favorit kini setelah ada zonasi label sekolah favorit tidak 
lagi berlaku bagi sekolah tersebut. Berdasarkan beberapa masalah yang ditemukan karena penerapan sistem zonasi disamping efek positifnya, penulis menjadi tertarik untuk mengangkat suatu judul yaitu "Dampak Pemberlakuan Sistem Zonasi Terhadap Siswa SMP dan Terhadap Mutu Sekolah”.

\section{METODE PENELITIAN}

Metode yang digunakan dalam artikel yang berjudul "Dampak Pemberlakuan Sistem Zonasi Terhadap Mutu Pendidikan dan Peserta Didik" menggunakan pendekatan kepustakaan. Studi pustaka atau kepustakaan merupakan serangkaian kegiatan yang memuat metode pengumpulan data pustaka, membaca serta mencatat lalu mengolah bahan penelitian (Zed,2008). (Khatibah, 2011).

Dalam penelitian pustaka hal-hal yang dilakukan oleh penulis diantaranya : Pertama, penulis berhadapan langsung dengan teks atau data angka, bukan dengan pengetahuan langsung di lapangan. Kedua, data pustaka harus "siap pakai" artinya penulis tidak harus melakukan penelitian langsung melainkan dengan melihat atau berhadapan dengan sumber data yang di pergunakan. Berdasarkan hal tersebut artinya pengumpulan data dilakukan dengan melakukan eksplorasi terhadap beberapa sumber data seperti Jurnal, buku, dan dokumen-dokumen lain yang relevan (baik dalam bentuk cetak maupun elektronik). Penelitian ini bersifat kualitatif yang lebih mengutamakan penggalian, penemuan, serta penyampaian data yang dikumpulkan. Analisis yang digunakan bersifat deskriptif , teoritis dan filosofis

\section{HASIL DAN PEMBAHASAN}

\section{Apa Itu Sistem Zonasi ?}

Pelaksanaan Penerimaan peserta didik baru (PPDB) mengacu pada Permendikbud No.51 Tahun 2018 yangmana prinsip dari peraturan tersebut adalah penerimaan peserta didik baru haruslah nondiskriminatif, objektif, transparan, akuntabel, dan berkeadilan untuk mendorong peningkatan akses layanan pendidikan. Dalam pemberlakuan kebijakan zonasi di Indonesia penerimaan peserta didik baru haruslah berpaku pada : pertama , Jarak tempat tinggal calon peserta didik ke sekolah haruslah sesuai dengan ketentuan zonasi, kedua, nilai hasil UN (bagi lulusan SMP) dan ketiga , prestasi peserta didik itu sendiri.

Dalam kebijakan tersebut hal-hal yang harus diperhatikan adalah : pertama , sekolah yang diselenggarakan oleh pemerintah wajib menerima calon peserta didik dengan radius zona terdekat dengan kuota minimal 90\% dari total keseluruhan 
peserta didik yang diterima. Kedua, domisili peserta didik dilihat dari KK (Kartu Keluarga) yang diterbitkan paling lambat enam bulan sebelum pelaksanaan penerimaan peserta didik baru (PPDB). Ketiga , radius jarak terdekat ditentukan oleh pemda sesuai karakteristik daerah yang bersangkutan dengan memperhatikan ketersediaan anak usia sekolah didaerah tersebut. Keempat, penetapan radius dibuat dengan musyawarah kepala sekolah. Untuk calon peserta didik yang berada diluar zona tetap dapat di terima dengan catatan berprestasi , prestasi dapat berupa prestasi akademik maupun non-akademik (kuota penerimaan 5\% dari total keseluruhan yang diterima). Selanjutnya alasan pindah domisili dengan alasan bencana alam (kuota 5\% dari total keseluruhan yang diterima) (Dhani Arba, 2019)

Zonasi muncul akibat munculnya keluhan dari orangtua murid yang merasa tersisihkan akibat sekolah yang hendak di masuki lebih mengutamakan nilai yang bagus sehingga mengakibatkan anaknya kalah dengan anak lain yang memiliki nilai yang lebih tinggi dan sesuai kriteria yang diinginkan oleh sekolah tersebut. Sehingga mereka harus mencari sekolah lain yang bisa menerimanya dengan konsekuensinya jarak tempuh dari rumah menuju sekolah lumayan jauh, atau orangtua peserta didik terpaksa menyekolahkananaknya ke sekolah swasta yangmana sekolah swasta lebih memakan biaya daripada sekolah yang diselenggarakan oleh pemerintah, untuk masyarakat yang memiliki kondisi ekonomi yang rendah tentunya hal ini menjadi beban bagi mereka.

\section{Penyebab Permasalahan Zonasi}

Penerapan dari sistem zonasi tentunya menimbulkan beberapa masalah, berikut di uraikan beberapa penyebab munculnya masalah penerapan Sistem Zonasi :

a. Kurangnya Sosialisasi

Sosialisasi yang dilakukan kepada camat, lurah, kepala sekolah, serta tokoh masyarakat ternyata belum mampu menjangkau orangtua atau wali murid sehingga konsep maupun tujuan dari penerapan Sistem Zonasi dirasa kurang dapat di mengerti oleh orangtua dan wali murid. Masih banyak sekolah yang mencoba memanipulasi data jarak rumah, mencoba untuk memperjual-belikan kursi sekolah favorit.

b. Kendala Teknis

Sistem Zonasi merupakan hal baru dalam sejarah pendidikan di Indonesia , masih ada kendala dalam penerimaan peserta didik baru terutama pada tahap seleksi daring. Ketersediaan sumber daya manusia sebagai operator daring 
kurang memadai, selain itu tidak semua orangtua atau wali murid melek teknologi sehingga tidak dapat memonitor perkembangan seleksi daring.

c. Masih Tingginya Disparsitas Kualitas Antarsekolah

Tidak dapat di pungkiri bahwa disparsitas kualitas antar sekolah masih menjadi pekerjaan rumah bagi Kemendikbud yang harus segera dibenahi supaya semua sekolah layak untuk menuntut ilmu. Untuk tingkat SMP hanya 28,73\% ruang kelas yang baik di gunakan, yaitu sejumlah 99.853 ruang. Sisanya 247.739 ruang mengalami rusak ringan, sedang, berat atau total. Selain sarana dan prasarana, sumber daya manusia seperti kepala sekolah, guru dan tenaga kependidikan lainnya yang dituntut untuk mensukseskan program baru ini dirasa kurang memenuhi syarat. Hanya 49\% guru yang mendapatkan sertifikasi, hal ini tentunya tidak memenuhi standar kualitas yang diperlukan sekolah. (Rudi, 2018).

\section{Dampak Positif dan Negatif Penerapan Sistem Zonasi}

a. Dampak Positif

1. Menguntungkan calon peserta didik yang rumahnya dekat karena walaupun nilai ujiannya tidak tinggi tetap dapat diterima di sekolah yang dekat dengan rumahnya , selain itu akan menghemat biaya dan tenaga menuju ke sekolah.

2. Pemerataan Pendidikan Dengan adanya sistem zonasi maka semua golongan masyarakat akan lebih mudah dalam mendapatkan layanan pendidikan, hal ini dikarenakan setiap orang dapat bersekolah ditempat yang mereka inginkan tanpa takut tidak akan diterima karena posisinya tergeser oleh calon peserta didik yang lebih unggul dibidang akademik maupun non-akademik. Sehingga akses mendapatkan layanan pendidikan menjadi lebih mudah. Selain itu calon peserta didik yang mengalami kekurangan dalam bidang ekonomi akan dimudahkan dengan jarak menuju sekolah yang dekat sehingga tidak perlu mengeluarkan biaya untuk mencapai ke lokasi sekolah. Selain itu upaya pemerintah dalam menyalurkan anggaran seperti penyediaan fasilitas serta sarana dan prasarana menjadi lebih merata

3. Menghilangkan Diskriminasi Sekolah. Dampak dari pemberlakuan zonasi lainnya adalah menghilangkan diskriminasi sekolah, sebelum zonasi di berlakukan banyak masyarakat yang memberi label "Sekolah Favorit" kepada sekolah-sekolah yang dianggap memiliki peserta didik yang memiliki keunggulan dibidang akademik dan non-akademik sehingga masyarakat akan menjadi pilih-pilih dalam memilih tempat ia akan bersekolah yang mengakibatkan banyak sekolah-sekolah lain yang kekurangan jumlah peserta 
didik. Dari adanya zonasi maka label-label sekolah favorit dan non-favorit tidak akan berlaku lagi.

b. Dampak Negatif

1. Bagi calon peserta didik yang jarak antara rumah dan sekolah cukup jauh maka peluang untuk diterima sangat kecil walaupun nilai ujiannya bagus, sehingga dengan terpaksa calon peserta didik akan mencari sekolah yang dekat bukannya yang berkualitas, hal ini menjadi masalah karena pemerintah belum mampu menyetarakan setiap sekolah serta belum mampu mengatasi disparitas kualitas antar sekolah.

2. Kegiatan Belajar Mengajar. Dengan adanya zonasi ini mengakibatkan guru akan mengalami kebingungan dalam mengajar, hal ini terutama terjadi pada guru yang mengajar di sekolah favorit, guru tersebut awalnya berada di zona nyaman karena terbiasa mengajar peserta didik yang sudah unggul dalam bidang akademik dan non-akademik, setelah kebijakan baru di terapkan guru tersebut harus bekerja ekstra kuat untuk beradaptasi dengan peserta didik yang memiliki kemampuan yang berbeda-beda sehingga guru harus mempunyai kiat dan strategi mengajar yang tepat ditinjau dari karakteristik peserta didik yang berbeda-beda.

3. Menurunnya Motivasi Belajar. Penerapan zonasi juga berdampak pada motivasi belajar anak, peserta didik akan kehilangan motivasinya dan daya saingnya untuk meraih nilai yang maksimal karena ia tahu bahwa bagus atau tidak nilainya ia akan tetap di terima disekolah yang ada di dekat lokasi domisilinya sehingga calon peserta didik akan bersantai-santai dalam belajar dan kurang ada semangat untuk menjadi yang terbaik diantara temantemannya.

\section{Dampak Zonasi Terhadap Peserta Didik dan Mutu Sekolah}

a. Dampak Zonasi Terhadap Peserta Didik

Zonasi menciptakan suatu kondisi dimana terjadi perkumpulan antar siswa yang heterogen, heterogen yang dimaksud adalah beragam. Terjadinya perkumpulan siswa yang memiliki kapasitas dan kemampuan yang berbeda-beda ada yang memiliki kemampuan akademik yang tinggi ada pula yang rendah. Mereka bertemu disatu sekolah bisa juga menjadi satu kelas. Perbedaan ini menjadi tantangan bagi guru untuk mencari strategi mengajar yang tepat yang dapat menjawab permasalahan tersebut. 
Peserta didik yang memiliki kemampuan akademik yang tinggi biasanya sudah menguasai hal-hal dasar sehingga peserta didik tersebut akan merasa cepat bosan dan kurang tertantang, sehingga peserta didik yang memiliki kemampuan akademik yang tinggi akan cenderung menyepelekan dan malas-malasan , sehingga hal ini memberi dampak akan terhentinya pengetahuan peserta didik dititik itu aja tidak ada pembelajaran yang lebih tajam dan mendalam, sebaliknya hal-hal yang terlalu tajam dan mendalam tidak cocok jika diajarkan pada peserta didik yang memiliki kemampuan akademik yang rendah. Hal tersebut menimbulkan permasalahan dalam proses belajar mengajar karena guru akan kaget. Motivasi adalah kekuatan, dorongan, semangat atau tekanan psikologis yang berasal dari diri pribadi atau seseorang untuk melalukan sesuatu sesuai dengan kegendaknya .

Dengan adanya sistem zonasi peserta didik akan merasa tidak ada tantangan dalam belajar karena sudah merasa cukup dengan apa yang didapat. Selain itu motivasi belajar juga dapat hilang karena peserta didik tidak mendapatkan sekolah yang diinginkan sehingga semangat dalam menempuh pendidikan tidak maksimal. Contoh dari dampak zonasi khususnya untuk anak, beberapa waktu lalu ada seorang anak yang sekolah di salah satu SD favorit di Pekalongan ia hendak mendaftar di SMP yang menjadi idam-idamannya selama ini namun karena jarak tempuh dari rumah menuju sekolah jauh akhirnya anak itu tidak diterima di SMP yang diinginkannya alhasil ia kehilangan semangat lalu memutuskan untuk membakar semua piagam yang ia dapatkan, piagam yang dimusnahkan tersebut sejumlah 15 buah dengan jenis penghargaan seperti menulis halus, cerita islami, tilawah, adzan, nyanyi solo, nyanyi grup, dokter kecil dan lain sebagainya. Hal ini menyebabkan terjadinya kontra dalam masyarakat karena merasa bahwa kebijakan zonasi justru malah merepotkan masyarakat (Purnomo, 2019).

b. Dampak Zonasi Terhadap Mutu Sekolah

Tujuan dari adanya zonasi adalah pemerataan pendidikan di berbagai wilayah di Indonesia, sistem zonasi ada untuk menciptakan kesetaraan antar sekolah dalam peran dan tugasnya sehingga seluruh sekolah di Indonesia semuanya sama dan setara tidak ada perbedaan lagi antara sekolah favorit dan sekolah biasa. Dengan adanya pemerataan ini maka setiap daerah akan merasakan layanan pendidikan dengan jumlah peserta didik yang layak. Sehingga pemerintah akan lebih mudah dalam menyalurkan fasilitas dan sarana prasarana 
pendidikan. Dengan adanya kebijakan baru ini mau tidak mau pemerintah harus rata dan adil dalam memfasilitasi setiap sekolah sehingga mutu dari sekolah dapat meningkat, selain itu juga tenaga kependidikan juga harus professional dalam menghadapi kebijakan baru ini sehingga tenaga pendidikan yang professional juga turut meningkatkan mutu dari satuan pendidikan tersebut

\section{Upaya Yang Dapat Dilakukan Untuk Mensukseskan Sistem Zonasi}

Pelayanan pendidikan yang merata untuk seluruh lapisan masyarakat tanpa terkecuali , karena sejatinya memperoleh pendidikan merupakan hak segala bangsa seperti yang tertuang dalam UUD 1945 , oleh karena itu untuk mensukseskan penerapan Sistem Zonasi hal-hal yang perlu dilakukan adalah sebagai berikut :

a. Ada beberapa kecurangan yang terjadi seperti jual beli bangku sekolah untuk tetap bisa masuk ke sekolah yang diinginkan, oleh karena itu kecurangan seperti ini harus segera dihilangkan. Sejatinya zonasi dilakukan oleh pemerintah agar memudahkan dalam melakukan pemetaan anggaran populasi siswa, dan tenaga pendidik. Hal yang dapat dilakukan seperti : menyediakan fasilitas dan sarana prasarana yang memadai, pemerataan kurikulum di setiap sekolah, peningkatan mutu serta kualitas tenaga pendidik di setiap sekolah.

b. Perlu dilakukan sosialisasi sistem zonasi secara masif sebelum Sistem Zonasi diterapkan, agar pemerintah daerah dan masyarakat mampu memahami kebijakan tersebut secara komprehensif.

c. Kemendikbud dan Kemendagri perlu berkoordinasi sebelum benar-benar menerapkan kebijakan baru.

d. Persepsi masyarakat tentang predikat sekolah unggulan di rubah, persepsi tersebut dapat dirubah apabila terjadi pemerataan fasilitas sarana \& prasarana pendidikan, mutu sekolah, serta kurikulum. 


\section{SIMPULAN}

Pendidikan adalah usaha sadar dan terencana untuk mewujudkan suasana belajar dan proses pembelajaran agar peserta didik secara aktif mengembangkan potensi dirinya untuk memiliki kekuatan spiritual keagamaan, pengendalian diri, kepribadian, kecerdasan, akhlak mulia, serta keterampilan, yang diperlukan dirinya, masyarakat, dan Negara.

Dewasa ini sistem zonasi diberlakukan dalam pendidikan Indonesia dengan harapan mampu mewujudkan layanan pendidikan yang merata di setiap daerah di Indonesia, karena pendidikan merupakan hak segala bangsa sesuai dalam isi yang tertuang dalam UUD 1945.

Dalam pelaksanaan Sistem Zonasi terdapat beberapa beberapa kendala seperti kendala teknis dan juga kurangnya Sumber Daya Manusia (SDM) yang memadai. Zonasi juga menimbulkan beberapa dampak baik yang positif dan juga negatif namun pemerintah tetap berupaya untuk meminimalisir dampak negatif yang ditimbulkan dari penerapan Sistem Zonasi.

\section{DAFTAR RUJUKAN}

Dhani Arba. (2019). Dampak Persebaran Populasi Penduduk Usia Sekolah Terhadap Penerimaan Peserta Didik Baru Melalui Sistem Zonasi Di Kabupaten Kebumen. SKRIPSI, 53(9), 1689-1699. https://doi.org/10.1017/CBO9781107415324.004

Kebudayaan, M. P. dan. (2018). PERATURAN MENTERI PENDIDIKAN DAN KEBUDAYAAN REPUBLIK INDONESIA Nomor 51 Tahun 2018 Tentang Penerimaan Peserta Didik Baru Pada Taman Kanak-Kanak, Sekolah Dasar, Sekolah Menengah Pertama, Sekolah Menengah Atas, Dan Sekolah Menengah Kejuruan. Permendikbud, 1-26.

Khatibah. (2011). PENELITIAN KEPUSTAKAAN. Jurnal Iqra', 0(01), 36-39.

Nasional, U. S. P. (2003). UNDANG-UNDANG REPUBLIK INDONESIA NOMOR 20 TAHUN 2003 TENTANG SISTEM PENDIDIKAN NASIONAL. Permendikbud, 71, 6-6. https://doi.org/10.1111/j.1651-2227.1982.tb08455.x

Pt, F. J. S., \& Arnilya, L. (2019). PENGARUH PENGGUNAAN MEDIA PEMBELAJARAN AUDIO-VISUAL DENGAN MICROSOFT POWERPOINT TERHADAP KEAKTIFAN DAN STKIP PGRI Situbondo PENDAHULUAN Belajar merupakan sebagai proses perubahan perilaku sebagai hasil interaksi individu dengan lingkungannya . Perubahan p. Pendidikan Sains Dan Teknologi, 6(2), 1-14.

Purnomo, I. D. (2019). Dampak Sistem Zonasi, Pelajar Ini Tak Diterima di SMP Favorit, 15 Piagam Dibakar - Halaman 3 - Tribun Manado. https://manado.tribunnews.com/2019/06/27/dampak-sistem-zonasi-pelajar-initak-diterima-di-smp-favorit-15-piagam-dibakar?page $=3$

Rudi, M. (2018). Efektivitas Penerimaan Peserta Didik. X, 1-8. 